Western University

Scholarship@Western

Earth Sciences Publications

Earth Sciences Department

2016

\title{
Microbially induced sedimentary structures in the Paleoproterozoic, upper Huronian Supergroup, Canada
}

Carolyn Hill

The University of Western Ontario

Patricia I. Corcoran

The University of Western Ontario

Rohan Aranha

The University of Western Ontario

Fred Longstaffe

The University of Western Ontario, flongsta@uwo.ca

Follow this and additional works at: https://ir.lib.uwo.ca/earthpub

Part of the Geology Commons, and the Sedimentology Commons

Citation of this paper:

Hill, Carolyn; Corcoran, Patricia I.; Aranha, Rohan; and Longstaffe, Fred, "Microbially induced sedimentary structures in the Paleoproterozoic, upper Huronian Supergroup, Canada" (2016). Earth Sciences Publications. 9.

https://ir.lib.uwo.ca/earthpub/9 
Department of Earth Sciences, The University of Western Ontario, London, ON, Canada, N6A $17 \quad 5 B 7$

$22 *$ Corresponding author. E-mail: chill59@uwo.ca

23

26 Keywords: Huronian Supergroup, Paleoproterozoic, MISS, microbial mats, paleoenvironment, 27 tidal flat 


\section{Abstract}

The Paleoproterozoic Gordon Lake and Bar River formations, Huronian Supergroup, contain a variety of sedimentary structures in the Flack Lake area of Ontario, Canada, that have been considered of debatable origin. We identify these structures as microbially induced sedimentary structures (MISS). The preserved MISS are related to microbial mat destruction and decay, and include sand cracks, mat chips, remnant gas domes, pyrite patches, and iron laminae. A biological origin for the fossil structures is supported by their similarities to modern and ancient documented examples of MISS, the sand-dominated nature of the substrate in which they are preserved, and key microtextures identified in thin section. Microtextures include curled, frayed and layered mat chips, carbonaceous laminae, oriented grains, and concentrated heavy minerals. On outcrop scale, the presence of desiccation cracks, flaser and lenticular bedding, and ripples in association with the types of MISS identified in the Gordon Lake Formation support the interpretation of a tidal flat depositional environment. The Gordon Lake Formation contains a greater number and diversity of MISS than the overlying Bar River Formation, as a result of lower energy deposition in the former. The quartz arenite of the Bar River Formation contains fine-grained to pebbly granulestone characterized mainly by tangential and planar cross beds, which is consistent with a tidal channel or sand shoal setting. Although fossil evidence of life is rare in the rocks of the Huronian Supergroup, identification of MISS in the Flack Lake area provides a significant and convincing indication of microbial colonization at the time of deposition.

\section{Introduction}

Microbially induced sedimentary structures (MISS; Noffke et al., 1996) develop during growth, metabolism, destruction and decay of microbial mats in siliciclastic-dominated environments (Schieber, 2004; Noffke, 2010). These microbial mats, or biofilms, encrust siliciclastic substrates in diverse natural environments (Gerdes, 2007; Noffke and Chafetz, 2012 and references therein). Although biofilms have existed for billions of years, their preservation in the rock record is highly dependent on the presence of more complex life forms. The majority of

57 Earth's Proterozoic eon was devoid of eukaryotic organisms. This would have enabled microbial mats to readily colonize clastic sedimentary deposits without the interference of grazers, thereby 
59 improving the cohesiveness of sand grains and decreasing erodibility of the sediment (Schieber

60 et al., 2007a; Sarkar et al., 2008; Eriksson et al., 2012). Microbially induced sedimentary

61 structures are therefore an invaluable trace fossil when working with Precambrian sedimentary

62 rocks. Numerous structures interpreted as having been related to microbial activity have been

63 described in the literature (e.g. Hagadorn and Bottjer, 1997; Gehling, 1999; Schieber et al.,

$642007 b$, and references therein; Noffke, 2010 and references therein), with several examples of

65 Paleoproterozoic MISS (e.g. Parizot et al., 2005; Banerjee and Jeevankumar, 2005; Chakrabarti

66 and Shome, 2010; Eriksson et al., 2012; Simpson et al., 2013). However, we are unaware of any

67 scientific publications reporting the preservation of MISS in rocks of the Paleoproterozoic

68 Huronian Supergroup.

69 Here we describe possible microbially induced sedimentary structures from the Gordon Lake

70 and Bar River formations, Huronian Supergroup. Identification of these structures is based on

71 comparisons with modern and other ancient analogues, as well as the six criteria for MISS

72 biogenicity as outlined in Noffke (2009). Recognizing different types of MISS in these rocks can

73 provide critical information regarding sedimentary processes, hydraulic energy, and

74 paleoenvironmental settings (Noffke, 2010; Bose and Chafetz, 2012).

\section{Geological Setting}

The Paleoproterozoic Huronian Supergroup forms part of the Southern Geological Province, and is well exposed along the north shore of Lake Huron, Canada (Fig. 1). The siliciclasticdominated, up to $12 \mathrm{~km}$ thick succession contains volcanic formations at the base of the stratigraphy (Fig. 2). Zircon from a lower rhyolite unit yielded a U-Pb date of ca. 2.45 Ga (Krogh et al., 1984; Ketchum et al., 2013), whereas an upper age limit of ca. 2.22 Ga was determined from primary baddeleyite in diabase intrusions that cut the stratigraphy (Corfu and Andrews, 1986). An alternative upper age limit of ca. $2.31 \mathrm{Ga}$ was proposed by Rasmussen et al. (2013), as

85 determined from zircon in purported tuff beds in the Gordon Lake Formation. However, Young (2014) argues that these zircons may be of detrital origin. the northwest (Card et al., 1977; Card, 1978; Young et al., 2001; Rousell and Card, 2009) and is overlain in the south by a Paleozoic succession with a depositional hiatus of 1.7 b.y. (Corcoran, 
2008). The Grenville Front Tectonic Zone separates the Southern and Grenville provinces to the southeast (Card, 1978; Rousell and Card, 2009). Rocks of the Huronian Supergroup in the study area have undergone subgreenschist to greenschist grade metamorphism, but the prefix "meta" is herein omitted for simplicity.

\section{Insert Figure 1 and 2 here}

Young and Nesbitt (1985) suggested that the Huronian Supergroup formed in a tectonic setting that evolved from rift basin to passive margin. Long (2004) later interpreted the succession as lower pull-apart basin to upper passive margin deposits. In contrast, Hoffman (2013) suggested that the entire Huronian succession was deposited along a passive margin. However, Young (2014) argued that the lower units have limited areal extent, show minor marine influence, display thickness changes across major faults, and contain seismic-related deposits, all of which suggest deposition in restricted fault-bound basins.

The Huronian Supergroup is composed of five groups, which include in ascending order, the Elliot Lake, Hough Lake, Quirke Lake, Cobalt and Flack Lake groups (Fig. 2). The cyclical nature of the Hough Lake, Quirke Lake and Cobalt groups form the basis for tripartite divisions consisting of lower diamictite, overlain by siltstone-mudstone-carbonate, and capped by sandstone (Roscoe, 1957; Wood, 1973; Card et al., 1977; Young et al., 2001; Long, 2004). The diamictite units are of glacial origin, whereas the overlying fine-grained formations are interpreted as deeper water deltaic deposits that formed following post-glacial sea level rise (Card et al., 1977; Robertson and Card, 1988; Long, 2009). The sandstone units in each division are mainly interpreted as fluvial deposits (McDowell, 1957; Long, 1978; Chandler, 1988a), although Rice (1986) suggested that the top of the Lorrain Formation (Cobalt Group) may be marine in origin. Young et al. (1991) suggested that the initiation of the Huronian glaciations was related to the formation of the supercontinent Kenorland. Increased exposure of the buoyant supercontinent enabled enhanced rates of continental weathering to occur, drawing down significant amounts of atmospheric $\mathrm{CO}_{2}$. The resultant drop in temperature would have initiated the process of glaciation. Alternatively, a decrease in the greenhouse effect during each cycle may have occurred through elimination of atmospheric $\mathrm{CH}_{4}$ during the rise of $\mathrm{O}_{2}$ (Pavlov et al., 2000; Tang and Chen, 2013). It has also been suggested that the two lower glaciogenic 
121 formations, the Ramsay Lake and Bruce, represent early deposition of detritus at the front edge

122 of a mountain ice sheet, which later grew into a continental ice sheet that deposited the thick and

123 laterally extensive Gowganda Formation (Eyles, 1993; Eyles and Januszczak, 2004; Young, 124 2014).

125 The Huronian Supergroup contains a record of the transition from an oxygen-deficient to 126 oxygen-rich Earth atmosphere, as recorded in the presence of detrital uranium-bearing minerals 127 in the Matinenda Formation (Elliot Lake Group), followed up-section by the first appearance of 128 red beds in the Gowganda Formation (Cobalt Group), red beds in the Lorrain Formation (Cobalt 129 Group), and red beds and evaporite minerals in the Gordon Lake Formation (Flack Lake Group) 130 (Wood, 1973). The MISS described in this study are preserved in the formations of the Flack 131 Lake Group.

\subsection{Flack Lake Group}

The Flack Lake Group consists of the Gordon Lake and Bar River formations (Fig. 2). The 300-760 m thick Gordon Lake Formation is composed of varicoloured siltstone, argillite, chert,

137 minor sandstone, and anhydrite and gypsum nodules (Card et al., 1977; Card, 1978, 1984;

138 Robertson, 1986; Chandler, 1986, 1988b). The presence of extensive red beds, evaporites and 139 hematite ooliths suggests that a significant amount of oxygen was present in the atmosphere 140 during deposition of these units (Wood, 1973; Chandler, 1988b; Baumann et al., 2011). Reported 141 sedimentary structures within siltstone and argillite units include planar laminations, graded 142 beds, convolute bedding, ball and pillow structures, desiccation cracks and synaeresis cracks, 143 whereas cross laminations and graded beds are common in the sandstone units (Wood, 1973; 144 Robertson, 1976; Card et al., 1977; Card, 1978, 1984; Chandler, 1986; Rust and Shields, 1987;

145 Bennett et al., 1991). Local dolostone containing fenestral cavities was identified near the base of 146 the formation (Hofmann et al., 1980). The sedimentary structures, combined with evaporite 147 minerals and fenestral fabrics, indicate deposition in a low-energy, tidal-flat, lagoonal or sabkha 148 environment (Wood, 1973; Card et al., 1977; Card, 1978, 1984; Chandler, 1986; Rust and 149 Shields, 1987). 
The conformably overlying, 100-900 m thick Bar River Formation is predominantly a quartz arenite succession with minor siltstone interbeds (Wood, 1973; Card et al., 1977, Card, 1978;

152 Chandler, 1984; Rust and Shields, 1987; Bennett et al., 1991). Sandstone units contain massive

153 beds, trough, tangential and planar cross-beds, ripple marks, herringbone cross-stratification, and

154 granule-pebble lags, whereas desiccation cracks and synaeresis cracks are common in the

155 siltstone units (Wright and Rust, 1985; Rust and Shields, 1987; Bennett et al., 1991). Roscoe and

156 Frarey (1970) suggested that the Bar River Formation was deposited in a fluvial environment

157 with mature quartz grains being derived from a regolith source. In contrast, Wood (1973)

158 proposed that the Bar River Formation represents a beach deposit that was subjected to aeolian

159 influence. However, the sedimentary structures, polymodal and bimodal paleocurrent patterns,

160 and textural and compositional maturity are more consistent with deposition in a near-shore,

161 shallow marine environment (Pettijohn, 1970; Robertson, 1976; Card, 1978; Chandler, 1984;

162 Rust and Shields, 1987; Bynoe, 2011). More specifically, Rust and Shields (1987) suggested that

163 the Bar River Formation in the Flack Lake area may have been deposited in a tidal channel

164 environment.

165 To date, there is no consensus on the depositional settings represented by the Gordon Lake

166 and Bar River formations, although most authors agree that the succession reflects deposition

167 along a continental shelf. We postulate that the predominance of certain types of MISS may help

168 in recognizing the physical sedimentary dynamics and associated depositional setting(s) of the

169 top-most formations of the Huronian Supergroup.

170 We studied the deposits of the Gordon Lake and Bar River formations in the Flack Lake area,

171 near Elliot Lake, Ontario (Fig. 1). The rocks were mapped in detail along Highway 639 and

172 along the shoreline of Flack Lake. In this area, the contact between the Bar River Formation and

173 the underlying Gordon Lake Formation is obscured by a diabase sill. Exposed sections are

174 predominantly flat-lying to gently dipping.

175

3. Upper Huronian Supergroup MISS

178 Young (1967) proposed that the Gordon Lake and Bar River formations near Flack Lake

179 contained organic vermiform casts, but he later discounted that finding by attributing the 
elliptical, spindle-shaped and overlapping structures to infilling of shrinkage cracks both from above and below (Young, 1969). Donaldson (1967) suggested that the spindle-shaped structures described from the Flack Lake area in addition to similar structures described from Michigan

183 (e.g. Faul, 1949; Frarey and McLaren, 1963; Hofmann, 1967; Young, 1967) may have formed 184 from desiccation of algal mats. Since that time, the sedimentology of the Gordon Lake and Bar 185 River formations in the Flack Lake area has been investigated by several workers (e.g. Wood, 186 1973; Card et al., 1977; Wright and Rust, 1985; Chandler, 1986, 1988a, 1988b; Rust and Shields, 187 1987; Robertson and Card, 1988). However, these authors indicated that the abundant polygonal, 188 linear and elliptical structures in the rocks were desiccation or synaeresis cracks. Although our present detailed investigation affirms that the polygonal structures are desiccation cracks, the spindle-shaped, overlapping linear structures are consistent with microbially induced sedimentation. These structures are herein described according to Schieber's (2004) processrelated classification scheme, which includes development during mat growth, metabolism,

193 physical destruction, and decay. Only the latter two categories of structures were identified in the 194 Flack Lake area.

\subsection{Mat-Destruction Structures} from rupturing of an overlying microbial mat that has been placed under stress from wind or water, or desiccation (Gerdes, 2007; Eriksson et al., 2007b). Impressions of the tears in the mat may be preserved in the underlying sand or silt. Cracks representing single incipient tears were identified in quartz arenite of the Bar River Formation and siltstone of the Gordon Lake Formation, and range from $0.5-1.5 \mathrm{~cm}$ in size (Fig. 3a). Sand-filled, $0.5-9.5 \mathrm{~cm}$ triradiate cracks are common in sandstones of both formations, and are inferred to have formed when sand was transported to the mat surface and filled the open ruptures from above (Fig. 3b). Fine-grained sandstones and siltstones of the Gordon Lake Formation preserve abundant, up to $30 \mathrm{~cm}$ long, lenticular, curved, sinuous, and spindle-shaped cracks (Fig. 3c, d). These irregular structures, unlike polygonal mud cracks that form through desiccation, reflect the elasticity of microbial mats, in which tearing results in curved or upturned margins (Gerdes, 2007). Although less 
211 common in the Bar River Formation, curved cracks at one locality were clearly infilled with sand 212 from above (Fig. 3e). Locally, cm-size cracks characterize the crests of interference ripples (Fig.

213 3f). These cracks are interpreted to have formed when fluid was expelled from microbial mats

214 that colonized the ripple crests. Desiccation of the mat may have also led to the formation of

215 these cracks.

\section{Insert Table 1 here}

221 forming curved, irregular fragments (Schieber, 2004; Erikssen et al., 2007a). Small mat chips, 2-

$2223.5 \mathrm{~cm}$ long, were identified in iron-stained Bar River quartz arenite at one locality (Fig. 4a).

223 Microbial sand and silt chips are 0.25-9 cm long, and were identified mainly in the Gordon Lake

224 Formation (Fig. 4b-d). These structures develop from abrasion of flipped-over mat margins by

225 water or wind, and are normally preserved as rounded or elongated fragments (Erikssen et al.,

226 2007a). Large mat chips were identified only in the siltstone and fine-grained sandstone of the

227 Gordon Lake Formation, and range from 7-150 cm long and 3-30 cm wide (Fig. 4d-f). The edges

228 of the large mat chips are sharp, frayed or irregular. Small chips appear to have been curled (Fig.

$2294 \mathrm{e}$ ), which is consistent with erosion of a dried out mat in an environment that is proximal to the

230 site of deposition (Schieber, 2007). Larger, uncurled mat chips contain biolamination and smaller

231 microbial mat chips (Fig. 4d), which suggest that the mat was wet during erosion (Schieber,

232 2007). One mat chip appears to have a mottled texture (Fig. 4f), which probably reflects mat

233 growth prior to erosion.

\subsection{Mat-Decay Structures}

Microbial mat decay in the Flack Lake area is indicated by remnant gas domes, pyrite

239 Gordon Lake Formation, where they are characteristically associated with iron staining (Fig. 5a).

240 The domes are 1-2 $\mathrm{cm}$ across and are surrounded by curved sand cracks. The domes appear to be 
241 ruptured locally, resembling radial gas escape structures (c.f. Dornbos et al., 2007; Fig. 5b), but 242 these characteristics may also be the results of dome erosion during Pleistocene glaciation.

243 Pyrite patches were identified in the troughs of interference ripples in Bar River quartz 244 arenite at one locality (Fig. 5c). The pyrite patches are inferred to represent the locations of

245 former microbial mats. The lower portions of a microbial mat are typically anoxic due to the 246 decay of organic matter; this environment is conducive to the formation of reduced minerals, 247 such as pyrite (Berner, 1984; Gerdes et al., 1985). Microbial mats were presumably the dominant 248 source of organic matter during the Paleoproterozoic and would have provided the necessary 249 organic debris within sand of the Bar River Formation at the time of deposition. Iron laminae 250 were identified in quartz arenite of the Bar River Formation at two localities, where they are 251 wavy (Fig. 5d) and cross-laminated. In general, purple, iron-rich laminae are thinner than pink, 252 quartz-rich laminae. The darker laminae may represent periods of calm hydrological conditions 253 during which microbial mats were able to grow, whereas the pink laminae may represent periods 254 of higher energy conditions during which growth of microbial mats was limited (Noffke et al., 255 2002; Druschke et al., 2009). The permeability of sandstones causes organic matter to be 256 removed fairly early in burial history, therefore the stratiform iron laminae represent residual 257 layers of mat-decay minerals (Schieber et al., 2007b).

\section{Insert Figure 4 here}

\section{Insert Figure 5 here}

\section{Criteria for the biogenicity of MISS in the upper Huronian Supergroup}

Fossil sedimentary structures of the Gordon Lake and Bar River formations in the Flack Lake area fulfill the six criteria for biogenicity, as outlined by Noffke (2009), and are therefore defined as MISS. The first criterion is that the sedimentary rocks must not have been subjected to metamorphism greater than greenschist grade. The studied rocks in the Flack Lake area are of subgreenschist metamorphic grade (Card, 1978). The second criterion states that the sedimentary

270 Group has been interpreted to have occurred along a continental shelf. Detailed geological mapping of the Gordon Lake Formation in the Flack Lake area supports deposition on a tidal 
272 flat, whereas the overlying Bar River Formation in the study area contains structures consistent

273 with a tidal channel or estuarine sand shoal environment. The stratigraphic relationship is

274 therefore consistent with a transgression. However, the occurrence of a regression is not

275 preserved unless the transition from the Lorrain Formation to the overlying Gordon Lake

276 Formation supports a falling water level. The majority of the Lorrain Formation is inferred to

277 have been deposited in a fluvial environment, which does not fit a regressive sequence.

278 However, a regression may have taken place following deposition of the Bar River Formation,

279 although any overlying units have been eroded away.

280 The third criterion of Noffke (2009) is that the structures are part of the "microbial mat

281 facies", which involves preferential microbial mat development on quartz-rich, fine-grained sand

282 that is frequently associated with small-scale ripples. The ideal environment for establishment of

283 a microbial colony is one of moderate energy in which currents and waves are not strong enough

284 to damage or destroy the microbial mat. However, depositional energy must be strong enough

285 that mud and other fine grains remain in suspension, thereby reducing the likelihood of sunlight

286 obstruction (Noffke, 2009). In the Flack Lake area, MISS of the upper Huronian Supergroup are

287 preserved on quartz-rich, fine-grained sandstone and siltstone beds, repeatedly on and in the

288 stratigraphic vicinity of rippled bedding planes.

289 Criterion 4 states that the distribution of the structures reflects the hydrodynamic conditions

290 of the depositional environment. The types of MISS identified in the Gordon Lake Formation are

291 consistent with distribution in an intertidal to supratidal setting. These environments experience a

292 complex array of hydrodynamic conditions and are therefore generally colonized by more robust

293 organisms, such as microbial mats. These mats influence the erosion and deposition of sediment,

294 thereby resulting in MISS (Noffke and Krumbein, 1999). Models of both ancient and modern

295 MISS distribution in siliciclastic tidal environments illustrate that small mat chips are found in

296 the lower intertidal zone, sand cracks in the upper intertidal to lower supratidal zones, and gas

297 domes in the upper intertidal to supratidal zones (Noffke et al., 2001; Dornbos et al., 2007; Bose

298 and Chafetz, 2009; Noffke, 2009; Tang et al., 2012). Large mat chips may also be found in the

299 intertidal zone (Noffke et al., 2013). The sedimentary structures of both formations reflect

300 deposition in a shallow marine, tidally-influenced environment, and the identified MISS (Table

301 1) are consistent with this interpretation. Criterion 5 of Noffke (2009) states that the structures

302 resemble and compare geometrically to modern MISS. Microbially induced sedimentary 
structures appear to have remained largely unchanged throughout Earth's history, thus the

304 comparison of ancient MISS to modern analogues is not only appropriate, but is integral for 305 determination of a biogenic origin (Noffke, 2009). Examples of modern and ancient MISS (e.g. 306 Dornbos et al., 2007; Eriksson et al., 2007b; Bose and Chafetz, 2012; Tang et al., 2012; Lan et 307 al., 2013; Noffke et al., 2013; Cuadrado et al., 2014) are comparable to the various forms of 308 MISS identified in the Gordon Lake and Bar River formations presented herein.

309 The final criterion for biogenicity of MISS requires that microtextures identified in thin 310 section denote a relationship to biofilms or microbial mats. In addition to the mesoscopic 311 structures identified in the Flack Lake outcrops, thin sections from the Gordon Lake Formation 312 reveal a variety of microtextures that are characteristic of microbial mat activities, such as 313 growth and trapping. Wavy crinkled laminae, 0.55-3.25 mm torn mat chips and 0.2-1.8 mm mat 314 chips are interpreted as portions of ancient microbial mat layers (Fig. 6a-e). Mat chips formed 315 during erosion and transportation of microbial mats. Locally, the mat chips are layered, which 316 reflects successive periods of mat growth prior to erosion (Fig. 6d), whereas folded mat chips are 317 consistent with transport of eroded material (Fig. 6d). Bands of concentrated heavy minerals may 318 represent the edge of a once-present mat layer (Noffke, 2009). Heavy minerals accumulate on mat surfaces where they are trapped and bound to the sticky mat exterior (Gerdes, 2007; Noffke, 2009). Oriented grains, 0.1-0.2 $\mathrm{mm}$ in size, are also identified in thin section (Fig. 6f). These structures develop when gas production in submerged microbial mats, or desiccation of a subaerial mat causes the mat to break into fragments, which then float and are deposited on muddy sediment (Eriksson et al., 2007b; Schieber, 2007). The positive identification of microbial mat chips on a microscopic scale, as illustrated in Figure 6a-f, meets the final criterion for 325 biogenicity of MISS in the sedimentary deposits of the Flack Lake Group.

Insert Figure 6 here

\section{Discussion}

Previous reports of biosignatures in the Paleoproterozoic Huronian Supergroup include stromatolites in the carbonate-rich Espanola Formation (Hofmann et al., 1980; Bekker et al., 2005; Long, 2009; Al-Hashim, 2015) and laminated fenestral dolostone in the Gordon Lake 
334 Formation at one locality (Hofmann et al., 1980). The identification of MISS in this study has

335 significantly increased the quantity of biosignatures reported from the Huronian Supergroup, and contributes to the relatively small group of reported Paleoproterozoic examples.

337 Sand cracks in the study area have previously been interpreted as shrinkage or synaeresis 338 cracks (e.g. Young, 1969; Card, 1978; Chandler, 1984, 1986; Wright and Rust, 1985; Rust and 339 Shields, 1987). Synaeresis cracks are narrow, curved to linear, tapering structures that have a 340 non-polygonal pattern in plan view and contorted sides in cross-section (Pratt, 1998; Harazim et al., 2013; Davies et al., 2016). Although there is much debate on the mechanism of formation of synaeresis cracks, many authors agree that the structures form in muddy sediment through the rapid shrinkage of clay under changing salinity conditions in a shallow submarine environment (Jüngst, 1934; White, 1961). Other proposed methods of formation include: desiccation (Allen, 1982), desiccation and infilling of evaporite molds (Astin and Rogers, 1991), seismic deformation (Pratt, 1998), and microbial facilitation (Pflüger, 1999; Harazim et al., 2013). Harazim et al. (2013) determined that cracked mudstones of the Ordovician Beach Formation in Newfoundland, Canada, were colonized by microbial mats, whereas non-cracked mudstones show no indication of microbial mat development. The authors suggest that microbial mats may be a pre-requisite for intra-stratal shrinkage crack formation, however Davies et al. (2016) suggest that synaeresis cracks may be polygenetic in nature and that there is no universal mode of formation. The curved, spindle and lenticular structures in the study area are found primarily on fine-grained sandstone to siltstone beds in the stratigraphic vicinity of other varieties of MISS, thus favouring a mat-induced origin. Associated sedimentary structures, such as desiccation cracks and flaser and lenticular bedding, support deposition in an environment that experienced periods of subaerial exposure, which is contradictory to synaeresis crack formation, which generally occurs in a submerged environment. Many of the cracks are exposed on rippled bedding planes, indicating that the sediment was stabilized, presumably by biofilms. Pyrite grains, horizons and patches are also found in many of the outcrops with sand cracks and may have formed under reducing conditions created by the decay of microbial mats.

A greater diversity and quantity of MISS is preserved in the Gordon Lake Formation 362 compared to the Bar River Formation (Table 1). This discrepancy can be attributed to the 363 different depositional environments of the formations within a tidally-influenced setting. The 364 recurrence of desiccation structures in the Gordon Lake Formation documents numerous periods 
365 of subaerial exposure. Desiccation cracks were also identified in the Bar River Formation, but in

366 a comparably minor amount. The main rock types in which MISS of the Gordon Lake Formation

367 are found include thin siltstone and fine-grained sandstone beds. These beds are mainly planar to

368 wavy laminated and bedding planes display oscillation ripples, local interference ripples and

369 abundant desiccation cracks. Our interpretation is that the Gordon Lake Formation was deposited

370 on a tidal flat where microbial mats flourished during relatively calm water conditions (Fig. 7).

371 Large mat chips and microbial sand and silt chips would have developed during periods of strong

372 wind or wave action, which detached and transported mat chips to an adjacent location.

373 Microbial mat tears and chips are common in wet microbial mats in protected inter- and supra-

374 tidal environments due to the effects of wind shear on very shallow tidal ponds or directly on

375 exposed mats (Bouougri and Porada, 2012). Microbial shrinkage and sand cracks analogous to

376 the types observed in the Flack Lake area occur in the intertidal and lower supratidal zones and

377 often display a range of shapes that are linked to the maturity, cohesiveness, and the extent of

378 desiccation of the microbial mat (Eriksson et al., 2007a). In addition, gas domes generally occur

379 only in the intertidal zone (Dornbos et al., 2007). Similar MISS to those herein described are

380 reported from the tidally influenced Proterozoic succession of the southern North China Platform

381 (Tang et al., 2012), the Neoproterozoic peritidal deposits of the West African Craton (Bouougri

382 and Porada, 2002), and the Mediterranean coast of modern southern Tunisia (Eriksson et al.,

383 2007a).

\section{Insert Figure 7 here} such as tangential and planar cross-beds and granule-pebble lags suggest relatively higher energy conditions at the time of deposition compared with those during deposition of the Gordon Lake Formation. Sand cracks identified in fine- to medium-grained sandstone beds are a reflection of microbial influence, as microbial filaments increase the cohesiveness between sand- and silt-

393 2000). Microbial mats cannot form in a high-energy environment as they will be eroded before 394 they have sufficient time to establish. However, once established, a microbial mat is robust 395 enough to tolerate high-energy conditions (Noffke, 2010). This may account in part for the lower 
396 diversity and the reduced number of MISS in the Bar River Formation relative to the Gordon

397 Lake Formation. The coarser grained, more porous and permeable nature of the Bar River

398 Formation may have also contributed to poorer preservation of microbial mats.

399 Many examples of ancient MISS are found in coastal, passive margin settings (Schieber et

400 al., 2007a), thus the inferred deposition of the upper Huronian Supergroup along a continental

401 margin would be conducive to the development of MISS. The types of MISS identified in the

402 Gordon Lake and Bar River formations are valuable indicators of depositional environment and

403 support the interpretation of deposition in a transgressive, tide-influenced setting.

\section{Conclusions}

Paleoproterozoic microbial mats developed, decayed and were destroyed in shallow marine environments where they influenced sedimentation patterns. The structures described from the Gordon Lake and Bar River formations contribute substantial evidence for microbial colonization during deposition of the upper Huronian Supergroup. The varieties of sand cracks,

412 identified in the Flack Lake area satisfy the criteria for biogenicity as outlined by Noffke (2009).

413 The differences between the MISS identified in the two formations are a function of varying

414 composition and grain size, which are the direct results of water energy and depth in each

415 depositional environment.

\section{Acknowledgements}

418 We thank Steve Wood for thin section preparation and reviewer Nora Noffke for her constructive

419 comments. This project would not have been possible without funding provided by the Faculty

420 of Science, The University of Western Ontario.

\section{References}

424 Al-Hashim, M.H.M., 2015. Sedimentology and facies analysis of the Paleoproterozoic mixed 425 carbonate-siliciclastic Espanola Formation, Huronian Supergroup, Canada: Reassessment of depositional environments. Presented at AESRC 2015, Kingston, ON. 
428 Allen, J.R.L., 1982. Sedimentary structures, their character and physical basis Volume II.

Astin, T.R., and Rogers, D.A., 1991. "Subaqueous shrinkage cracks" in the Devonian of Scotland reinterpreted. Journal of Sedimentary Petrology 61, 850-859.

Baumann, S.D.J., Arrospide, T., and Wolosyzn, A.E., 2011. Preliminary redefinition of the Cobalt Group (Huronian Supergroup), in the Southern Geologic Province, Ontario,

Bekker, A., Kaufman, A. J., Karhu, J. A., and Eriksson, K. A., 2005. Evidence for

Bennett, G., Dressler, B.O., and Robertson, J.A., 1991. The Huronian Supergroup and associated intrusive rocks. In: Thurston, P.C., Williams, H.R., Sutcliffe, R.H., Scott, G.M. (Eds.),

Berner, R.A., 1984. Sedimentary pyrite formation; an update. Geochimica et Cosmochimica Acta 48, 605-615.

Bose, S., and Chafetz, H.S., 2009. Topographic control on distribution of modern microbially induced sedimentary structures (MISS): a case study from Texas coast. Sedimentary Geology 213, 136-149.

Bose, S., and Chafetz, H., 2012. Morphology and distribution of MISS: a comparison between modern siliciclastic and carbonate settings. In: Noffke, N., and Chafetz, H., (Eds) 
Microbial Mats in Siliciclastic Systems Through Time, SEPM Special Publication No. 101, Elsevier, pp. 3-14.

Bose, P.K., Sarkar, S., Banerjee, S., and Chakraborty, S., 2007. Mat-related features from sandstones of the Vindhyan Supergroup in Central India. In: Schieber, J., Bose, P.K., Eriksson, P.G., Banerjee, S., Sarkar, S., Altermann, W., and Catuneanu, O. (Eds) Atlas of Microbial Mat Features Preserved within the Siliciclastic Rock Record, Atlases in Geoscience 2, Elsevier, pp. 181-188.

Bouougri, E., and Porada, H., 2002. Mat-related sedimentary structures in Neoproterozoic peritidal passive margin deposits of the West African Craton (Anti-Atlas, Morocco). Sedimentary Geology 153, 85-105.

Card, K.D., 1978. Geology of the Sudbury-Manitoulin Area, Districts of Sudbury and Manitoulin. Ontario Geological Survey Report 166, 238p.

Card, K. D., 1984. Geology of the Espanola-Whitefish Falls Area, District of Sudbury, Ontario. Ontario Geological Survey, Report 131, 70p. Accompanied by Maps 2311, 2312, scale

Card, K. D., Innes, D. G., and Debicki, R. L., 1977. Stratigraphy, Sedimentology, and Petrology of the Huronian Supergroup of the Sudbury-Espanola Area. Ontario Division of Mines, OFR5107, 307 p. Accompanied by 4 charts and one figure. 
490 Chakrabarti, G., and Shome, D., 2010. Interaction of microbial communities with clastic

491 sedimentation during Palaeoproterozoic time - an example from basal Gulcheru

492 Formation, Cuddapah basin, India. Sedimentary Geology 226, 22-28.

494 Chandler, F.W., 1984, Sedimentary Setting of an Early Proterozoic Copper Occurrence in the 495 Cobalt Group, Ontario; A Preliminary Assessment, In: Current Research, Part A, 496 Geological Survey of Canada Paper 84-1A, 185-192.

Chandler, F.W., 1986. Sedimentology and paleoclimatology of the Huronian (Early Aphebian) Lorrain and Gordon Lake Formations and their bearing on models for sedimentary copper

Chandler, F.W., 1988a. Quartz arenites: review and interpretation. Sedimentary Geology 58, mineralization. Geological Survey of Canada Paper 86-1A, 121-132.

Chandler, F.W., 1988b. Diagenesis of sabkha-related, sulphate nodules in the early Proterozoic 105-126.

Corfu, F. and Andrews, A.J., 1986. A U-Pb age for mineralized Nipissing diabase, Gowganda, Ontario. Canadian Journal of Earth Sciences 23, 107-109.

515 Cuadrado, D.G., Perillo, G.M.E., and Vitale, A.J., 2014. Modern microbial mats in siliciclastic tidal flats: Evolution, structures and the role of hydrodynamics. Marine Geology 352, 367380 . 
Davies, N.S., Liu, A.G., Gibling, M.R., and Miller, R.F., 2016. Resolving MISS conceptions and misconceptions: a geological approach to sedimentary surface textures generated by

Donaldson, J.A., 1967. Precambrian vermiform structures: a new perspective. Canadian Journal of Earth Sciences 4, 1273-1276.

Druschke, P.A., Jiang, G., Anderson, T.B., and Hanson, A.D., 2009. Stromatolites in the Late Ordovician Eureka Quartzite: implications for microbial growth and preservation in siliciclastic settings. Sedimentology 56, 1275-1291.

Eriksson, P.G., Bartman, R., Catuneanu, O., Mazumder, R., and Lenhardt, N., 2012. A case study of microbial mat-related features in coastal epeiric sandstones from the Paleoproterozoic Pretoria Group (Transvaal Supergroup, Kaapvaal craton, South Africa); The effect of preservation (reflecting sequence stratigraphic models) on the relationship between mat features and inferred paleoenvironment. Sedimentary Geology 263-264, 6775.

Eriksson, P.G., Porada, H., Banerjee, S., Bouougri, E., Sarkar, S., and Bumby, A.J., 2007a. Matdestruction features. In: Schieber, J., Bose, P.K., Eriksson, P.G., Banerjee, S., Sarkar, S., Altermann, W., and Catuneanu, O. (Eds) Atlas of Microbial Mat Features Preserved within the Siliciclastic Rock Record, Atlases in Geoscience 2, Elsevier, pp. 76-105.

Eriksson, P.G., Schieber, J., Bouougri, E., Gerdes, G., Porada, H., Banerjee, S., Bose, P.K., and Sarkar, S., 2007b. Classification of structures left by microbial mats in their host sediments. In: Schieber, J., Bose, P.K., Eriksson, P.G., Banerjee, S., Sarkar, S., Altermann, W., and 
Catuneanu, O. (Eds) Atlas of Microbial Mat Features Preserved within the Siliciclastic

Rock Record, Atlases in Geoscience 2, Elsevier, pp. 39-52.

Eriksson, P.G., Simpson, E.L., Eriksson, K.A., Bumby, A.J., Steyn, G.L., and Sarkar, S., 2000. Muddy roll-up structures in siliciclastic interdune beds of the c. 1.8 Ga Waterberg Group, South Africa. Palaios 15, 177-183.

Eyles, N., 1993. Earth's glacial record and its tectonic setting. Earth Science Reviews 35, 1-248.

Eyles, N., and Januszczak, N., 2004. 'Zipper-rift': a tectonic model for Neoproterozoic glaciations during the breakup of Rodinia after 750 Ma. Earth Science Reviews 65, 1-73.

Faul, H., 1949. Fossil burrows from the Pre-Cambrian Aiibik Quartzites of Michigan. Nature $164,32$.

Frarey, M.J., and McLaren, D.J., 1963. Possible metazoans from the Early Proterozoic of the Canadian Shield. Nature 200, 461-462.

Gehling, J.G., 1999. Microbial mats in terminal Proterozoic siliciclastics: Ediacaran death masks. Palaios 14, 40-57.

Gerdes, G., 2007. Structures left by modern microbial mats in their host sediments. In: Schieber, J., Bose, P.K., Eriksson, P.G., Banerjee, S., Sarkar, S., Altermann, W., and Catuneanu, O. (Eds) Atlas of Microbial Mat Features Preserved within the Siliciclastic Rock Record, Atlases in Geoscience 2, Elsevier, pp. 5-38.

Gerdes, G., Klenke, Th., and Noffke, N., 2000. Microbial signatures in peritidal siliciclastic sediments: a catalogue. Sedimentology 47, 279-308. 
Gerdes, G., Krumbein, W.E., and Reineck, H.-E., 1985. The depositional record of sandy, versicolored tidal flats (Mellum Island, southern North Sea). Journal of Sedimentary Petrology 55, 265-278.

Hagadorn, J.W., and Bottjer, D.J., 1997. Wrinkle structures: microbially mediated sedimentary structures common in subtidal siliciclastic settings at the Proterozoic-Phanerozoic transition. Geology 25, 1047-1050.

Harazim, D., Callow, R.H.T., and Mcilroy, D., 2013. Microbial mats implicated in the generation of intrastratal shrinkage ('synaeresis') cracks. Sedimentology 60, 1621-1638.

Hoffman, P.F., 2013. The Great Oxidation and a Siderian snowball Earth: MIF-S based correlation of Paleoproterozoic glacial epochs. Chemical Geology 362, 143-156.

Hofmann, H.J., 1967. Precambrian fossils (?) near Elliot Lake, Ontario. Science 156, 500-504.

Hofmann, H.J., Pearson, D.A.B., and Wilson, B.H., 1980. Stromatolites and fenestral fabric in early Proterozoic Huronian Supergroup, Ontario. Canadian Journal of Earth Sciences 17, $10,1351-1357$.

Jüngst, H., 1934. Zur geologischen bedeutung der synärese. Geologische Rundschau 15, 312 325.

Ketchum, K.Y., Heaman, L.M., Bennett, G., and Hughes, D.J., 2013. Age, petrogenesis and tectonic setting of the Thessalon volcanic rocks, Huronian Supergroup, Canada. Precambrian Research 233, 144-172.

Krogh, T.E., Davis, D. W., and Corfu, F., 1984. Precise U-Pb zircon and baddeleyite ages for the Sudbury Structure. In: Pye, E. G., Naldrett, A.J., Giblin, P.E. (Eds.), Geology and Ore Deposits of the Sudbury Structure, Ontario Geological Survey, v. 1, pp. 431-446. 
Lan, Z.-W., and Chen, Z.-Q., 2012. Proliferation of MISS-forming microbial mats after the late Neoproterozoic glaciations: evidence from the Kimberley region, NW Australia. Precambrian Research 224, 529-550.

Lan, Z.-W., Chen, Z.-Q., Li, X.-H., and Kaiho, K., 2013. Microbially induced sedimentary structures from the Mesoproterozoic Huangqikou Formation, Helan Mountain region, northern China. Precambrian Research 233, 73-92.

Long, D.G.F., 1978. Depositional environments of a thick Proterozoic sandstone, the (Huronian) Mississagi Formation of Ontario, Canada. Canadian Journal of Earth Sciences 15, 190-206.

Long, D.G.F., 2004. The tectonostratigraphic evolution of the Huronian basement and subsequent basin fill: geological constraints on impact models of the Sudbury event. Precambrian Research 129, 203-223.

Long, D.G.F., 2009. The Huronian Supergroup. In: Rousell, D.H., and Brown, G.H. (Eds.), A Field Guide to the Geology of Sudbury, Ontario: Ontario Geological Survey Open File Report 6243, pp. 14-30.

McDowell, J.P., 1957. The sedimentary petrology of the Mississagi quartzite in the Blind River area. Ontario Department of Mines, Geological Circular 6, 31p.

Noffke, N., 2009. The criteria for the biogeneicity of microbially induced sedimentary structures (MISS) in Archean and younger, sandy deposits. Earth-Science Reviews 96, 173-180.

Noffke, N., 2010. Geobiology: Microbial Mats in Sandy Deposits from the Archean Era to Today, Springer-Verlag, Berlin, 194p.

Noffke, N., Beukes, N., Gutzmer, J., and Hazen, R., 2006. Spatial and temporal distribution of microbially induced sedimentary structures: a case study from siliciclastic storm deposits of the 2.9 Ga Witwatersrand Supergroup, South Africa. Precambrian Research 146, 35-44. 
642 Noffke, N., and Chafetz, H., 2012. Introduction. In: Noffke, N., and Chafetz, H., (Eds) Microbial 643 Mats in Siliciclastic Systems Through Time, SEPM Special Publication No. 101, Elsevier, 644 pp. 1.

Noffke, N., Christian, D., Wacey, D., and Hazen, R.M., 2013. Microbially induced sedimentary structures recording an ancient ecosystem in the ca. 3.48 Billion-year-old Dresser

Noffke, N., Gerdes, G., Klenke, T., and Krumbein, W.E., 1996. Microbially induced sedimentary structures - examples from modern sediments of siliciclastic tidal flats. Zentralblatt für Geologie und Paläontologie, Teil I, H. 1/2, 307-316.

Noffke, N., Gerdes, G., Klenke, T., and Krumbein, W.E., 2001. Microbially induces sedimentary structures indicating climatological, hydrological and depositional conditions within recent and Pleistocene coastal facies zones (Southern Tunisia). Facies 44, 23-30.

665

Parizot, M., Eriksson, P.G., Aifa, T., Sarkar, S., Banerjee, S., Catuneanu, O., Altermann, W., Bumby, A.J., Bordy, E.M., Rooy, J.L.V., and Boshoff, A.J., 2005. Suspected microbial mat-related crack-like sedimentary structures in the Palaeoproterozoic Magaliesberg Formation sandstones, South Africa. Precambrian Research 138, 274-296. 
Pavlov, A.A., Kasting, J.F., and Brown, L.L., 2000. Greenhouse warming by $\mathrm{CH}_{4}$ in the atmosphere of early Earth. Journal of Geophysical Research 105, 11981-11990.

674 Pettijohn, F.J., 1970. The Canadian Shield-A Status Report, 1970. In: A. J. Baer, (Ed.), Symposium on Basins and Geosynclines of the Canadian Shield: Geological Survey of

Pflüger, F., 1999. Matground structures and redox facies. Palaios 14, 25-39.

Pratt, B.R., 1998. Syneresis cracks: subaqueous shrinkage in argillaceous sediments caused by earthquake-induced dewatering. Sedimentary Geology 117, 1-10.

Rasmussen, B., Bekker, A., and Fletcher, I.R., 2013. Correlation of Paleoproterozoic glaciations based on U-Pb zrcon ages for tuff beds in the Transvaal and Huronian Supergroups. Earth and Planetary Science Letters 382, 173-180.

Robertson, J.A., and Card, K.D., 1988. Geology and Scenery: North shore of Lake Huron Region. Ontario Geological Survey, Geological Guidebook 4.

Rice, R.J., 1986. Regional sedimentation in the Lorrain Formation (Aphebian), central Cobalt Embayment. In: Summary of Field Work and Other Activities: Ontario Geological Survey Miscellaneous Paper 137, 210-216.

Robertson, J.A., 1976. The Blind River uranium deposits: the ores and their setting. Ontario Division of Mines Miscellaneous Paper 65, 1-54.

Robertson, J.A., 1986. Huronian Geology and the Blind River (Elliot Lake) uranium deposits, the Pronto Mine. In: Uranium Deposits of Canada, Canadian Institute of Mining and Metallurgy, Special Paper 33, 46-43. 
Roscoe, S.M., 1957. Stratigraphy, Quirke Lake-Elliot Lake Senior, Blind River area, Ontario. Royal Society of Canada Special Publication Number 6, 54-58.

Roscoe, S.M., and Frarey, M.J., 1970. Comments on: The Canadian Shield - A status report, 1970, by F.J. Pettijohn. In: A. J. Baer, (Ed.), Symposium on Basins and Geosynclines of the Canadian Shield, Geological Survey of Canada Paper 70-40, 255-262.

Rousell, D.H., and Card, K.D., 2009. Sudbury area geology and mineral deposits. In: Rousell, D.H., and Brown, G.H. (Eds.) A Field Guide to the Geology of Sudbury, Ontario, Ontario Geological Survey Open File Report 6243, 1-6.

Rust B.R., and Shields M.J., 1987. The Sedimentology and Depositional Environments of the Huronian Bar River Formation, Ontario, Grant 189, Geoscience Research Grant Program. Ontario Geological Survey Open File Report, 1-37.

Sarkar, S., Bose, P.K., Samanta, P., Sengupta, P., and Eriksson, P.G., 2008. Microbial mat mediated structures in the Ediacaran Sonia Sandstone, Rajasthan, India, and their implications for Proterozoic sedimentation. Precambrian Research 162, 248-263.

Schieber, J., 2004. Microbial mats in the siliciclastic rock record: a summary of diagnostic features. In: Eriksson, P.G., Altermann, W., Nelson, D.R., Mueller, W.U., and Catuneanu, O. (Eds) The Precambrian Earth: Tempos and Events, Developments in Precambrian Geology, Elsevier 12, pp. 663-673.

Schieber, J., 2007. Micobial mats on muddy substrates - examples of possible sedimentary features and underlying processes. In: Schieber, J., Bose, P.K., Eriksson, P.G., Banerjee, S., Sarkar, S., Altermann, W., and Catuneanu, O. (Eds) Atlas of Microbial Mat Features Preserved within the Siliciclastic Rock Record, Atlases in Geoscience 2, Elsevier, pp. 117134. 
Schieber, J., Bose, P.K., Eriksson, P.G., and Sarkar, S., 2007a. Palaeoenvironmental and chronological relationships of mat-related features, and sequence stratigraphic implications of microbial mats. In: Schieber, J., Bose, P.K., Eriksson, P.G., Banerjee, S., Sarkar, S., Altermann, W., and Catuneanu, O. (Eds) Atlas of Microbial Mat Features Preserved within the Siliciclastic Rock Record, Atlases in Geoscience 2, Elsevier, 267-275.

Schieber, J., Bose, P.K., Eriksson, P.G., Banerjee, S., Sarkar, S., Altermann, W., and Catuneanu, O. (Eds), 2007b. Atlas of Microbial Mat Features Preserved within the Siliciclastic Rock Record, Atlases in Geoscience 2, Elsevier, 311 p.

Simpson, E.L., Heness, E., Bumby, A., Eriksson, P.G., Eriksson, K.A., Hilbert-Wolf, H.L., Linnevelt, S., Fitzgerald, M., Modungwa, T., and Okafor, O,J., 2013. Evidence for $2.0 \mathrm{Ga}$ continental microbial mats in paleodesert setting. Precambrian Research 237, 36-50.

Tang, D-J., Shi, X-Y., Jiang, G., and Wang, X-Q., 2012. Morphological association of microbially induces sedimentary structures (MISS) as a paleoenvironmental indicator: an example from the Proterozoic succession of the Southern North China Platform. In: Noffke, N., and Chafetz, H., (Eds) Microbial Mats in Siliciclastic Systems Through Time, SEPM Special Publication No. 101, Elsevier, pp. 163-175.

Tang, H., and Chen, Y., 2013. Global glaciations and atmospheric change at ca. 2.3 Ga. Geoscience Frontiers 4, 583-596.

White, W.A., 1961. Colloid phenomena in sedimentation of argillaceous rocks. Journal of Sedimentary Research 31, 560-570.

Wood, J., 1973. Stratigraphy and depositional environments of upper Huronian rocks of the Rawhide Lake-Flack Lake area, Ontario. The Geological Association of Canada Special Paper Number 12, 73-95. 
761 Wright, D.J., and Rust, B.R., 1985. Preliminary report on the stratigraphy and sedimentology of the Bar River Formation. In: Milne, V.G. (Ed.), Grant 189, Geoscience Research Grant Program, Summary of Research, 1984-1985, Ontario Geological Survey Miscellaneous Paper 127, pp. 119-123.

Young, G.M., 1967. Possible organic structures in early Proterozoic (Huronian) rocks of Ontario. Canadian Journal of Earth Sciences 4, 565-568.

Young, G.M., 1969. Inorganic origin of corrugated vermiform structures in the Huronian Gordon Lake Formation near Flack Lake, Ontario. Canadian Journal of Earth Sciences 6, 795-799.

Young, G.M., 2013. Precambrian supercontinents, glaciations, atmospheric oxygenation, metazoan evolution and an impact that may have changed the second half of Earth history. Geoscience Frontiers 4, 247-261.

Young, G.M., 2014. Contradictory correlations of Paleoproterozoic glacial deposits: Local,

Young, G.M., Long, D.G.F., Fedo, C.M., and Nesbitt, H.W., 2001. Proterozoic Huronian Basin: Product of a Wilson cycle punctuated by glaciations and a meteorite impact. Sedimentary Geology 141-142, 233-254.

Young, G.M., and Nesbitt, H.W., 1985. The lower Gowganda Formation in the southern part of the Huronian outcrop belt, Ontario, Canada: Stratigraphy, depositional environments and tectonic setting. Precambrian Research 29, 265-301. 
Table 1: Summary of the microbially induced sedimentary structures (MISS) identified in the

Gordon Lake and Bar River formations in the Flack Lake area.

Figure 1: Simplified geologic map of the distribution of the Huronian Supergroup north of Lake Huron. The study area is located $29 \mathrm{~km}$ north of Elliot Lake. Modified from Young et al. (2001) and Long (2009).

Figure 2: General stratigraphy of the Huronian Supergroup. Modified from Long (2004) and Young (2013). Date for Nipissing Diabase from Corfu and Andrews (1986). Date for Copper Cliff Formation from Krogh et al. (1984) and Ketchum et al. (2013).

Figure 3: Mat-destruction structures identified in the Flack Lake area. Scales include pencil $(14.5 \mathrm{~cm})$ and camera lens cap $(5.8 \mathrm{~cm})$. (A) Single incipient tears preserved in fine-grained sandstone of the Bar River Formation. (B) Triradiate cracks preserved in fine-grained sandstone of the Gordon Lake Formation. (C) Curved, sinuous sand cracks preserved in siltstone of the Gordon Lake Formation. (D) Curved, corrugated sand cracks preserved in siltstone of the Gordon Lake Formation. (E) Curved sand cracks filled from above preserved in fine-grained sandstone of the Bar River Formation. (F) Curved cracks confined to the crests of interference ripples preserved in fine-grained sandstone of the Bar River Formation.

Figure 4: Mat-destruction structures identified in the Flack Lake area. Scales include pencil $(14.5 \mathrm{~cm})$ and camera lens cap $(5.8 \mathrm{~cm})$. (A) Microbial mat chips preserved in iron stained,

813 fine-grained sandstone of the Bar River Formation. (B) Microbial sand and silt chips preserved in fine-grained sandstone of the Gordon Lake Formation. (C) Microbial sand and silt chips preserved in fine-grained sandstone of the Bar River Formation. (D) Microbial sand and silt chips preserved in fine-grained sandstone of the Gordon Lake Formation. 
Note the frayed margins of the large mat chip and the biolaminations below the pencil. (E) Microbial mat chips preserved in fine-grained sandstone of the Gordon Lake Formation. Note the curled appearance of these chips. (F) Large mat chips preserved in the same finegrained sandstone bed as Figure 4-E. Note the mottled appearance of the mat and distinct torn margins.

823 Figure 5: Mat-decay structures identified in the Flack Lake area. Pencil for scale $(14.5 \mathrm{~cm})$. (A) Remnant gas domes preserved in fine-grained sandstone of the Gordon Lake Formation.

832 Figure 6: Mat microtextures identified in thin sections from the Gordon Lake Formation. (A) Frayed mat chip preserved in fine-grained sandstone. Note the internal layering and torn

841 Figure 7. Schematic model showing the distribution of different MISS on a Paleoproterozoic barrier island-tidal flat system. The Gordon Lake Formation is represented by the sediments in the intertidal and lower supratidal settings. The Bar River Formation is represented by the sand ridges and barrier island. 
Mat-related Feature Sandcracks

single incipient tears

triradiate

curved

lenticular

spindle

sinuous

Microbial sand and silt chips

Large mat chips

Small mat chips

Remnant gas domes

Iron patches

Iron laminae
Gordon Lake Formation Bar River Formation
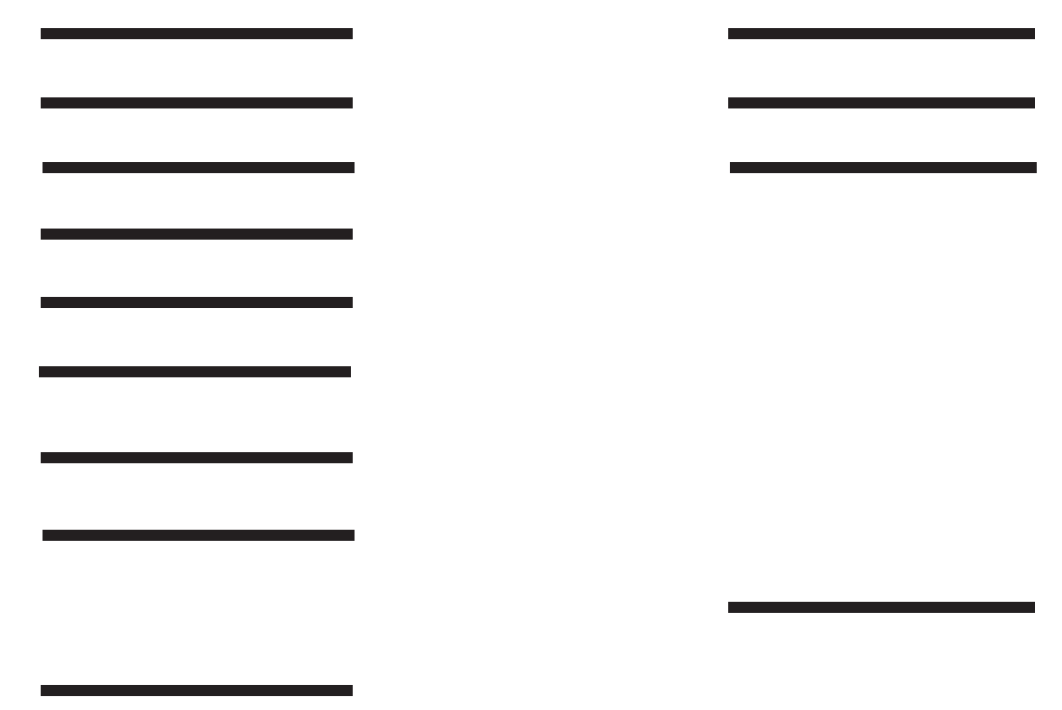


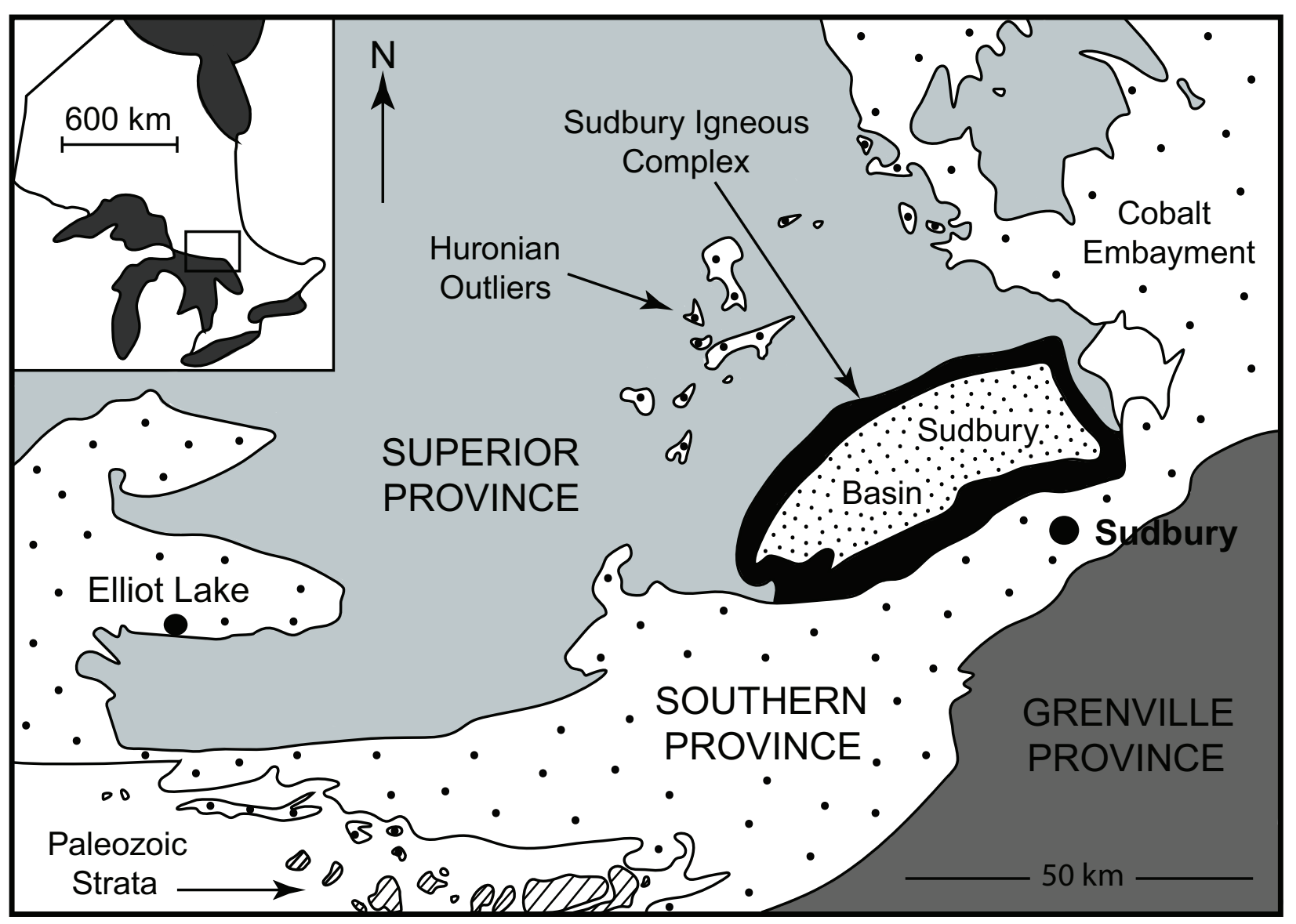




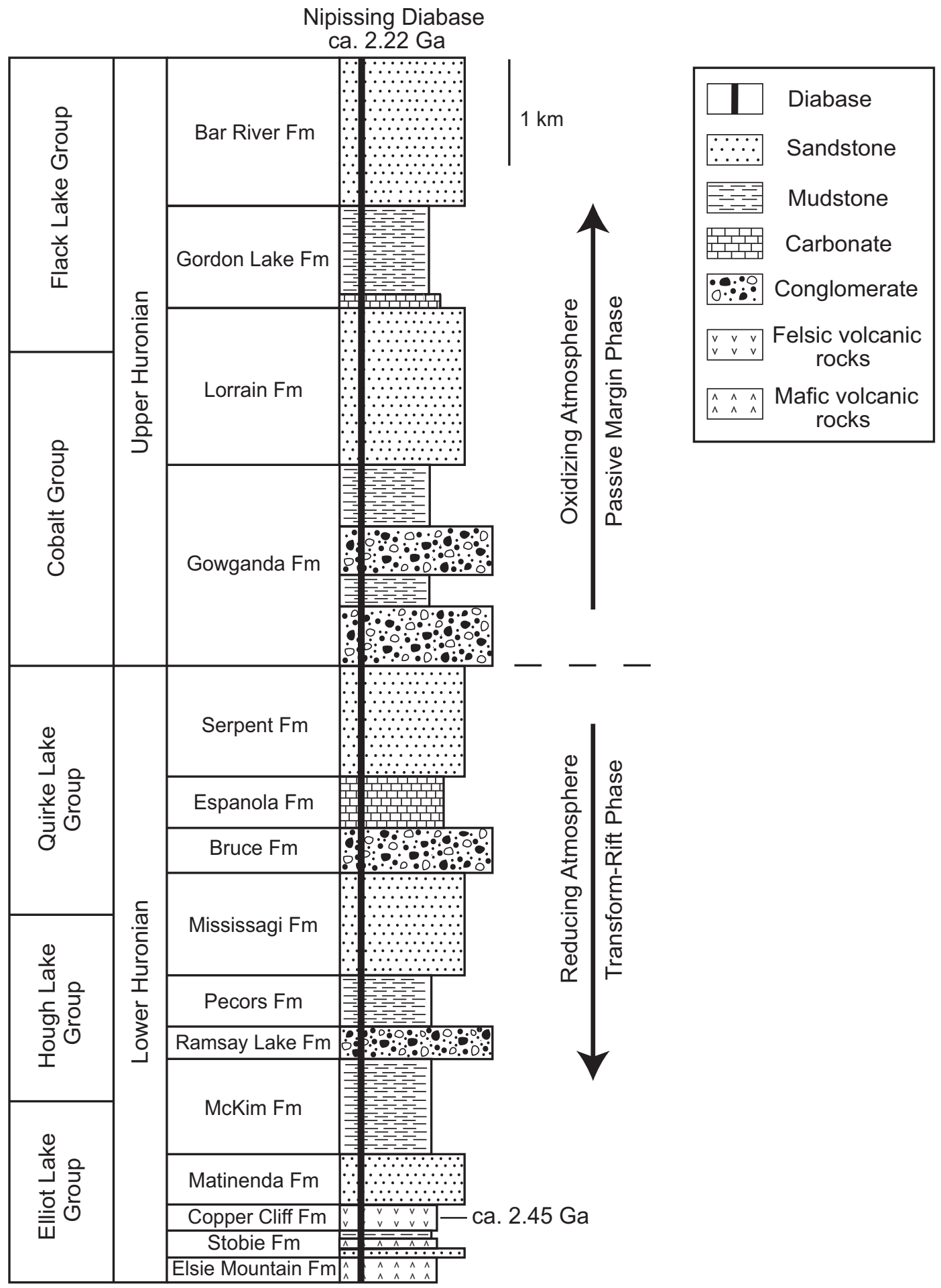




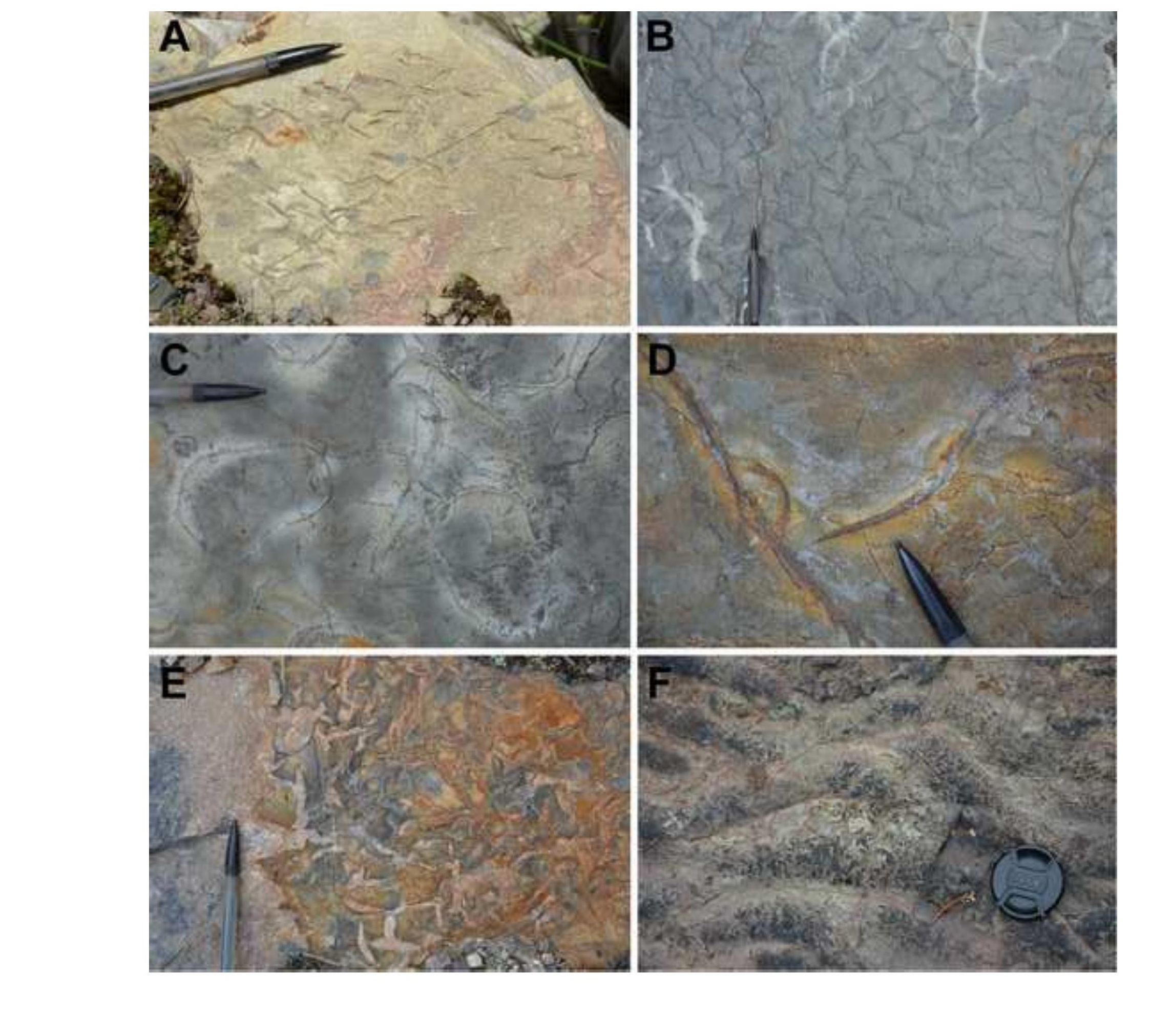

\section{Click here to download high resolution image}

.

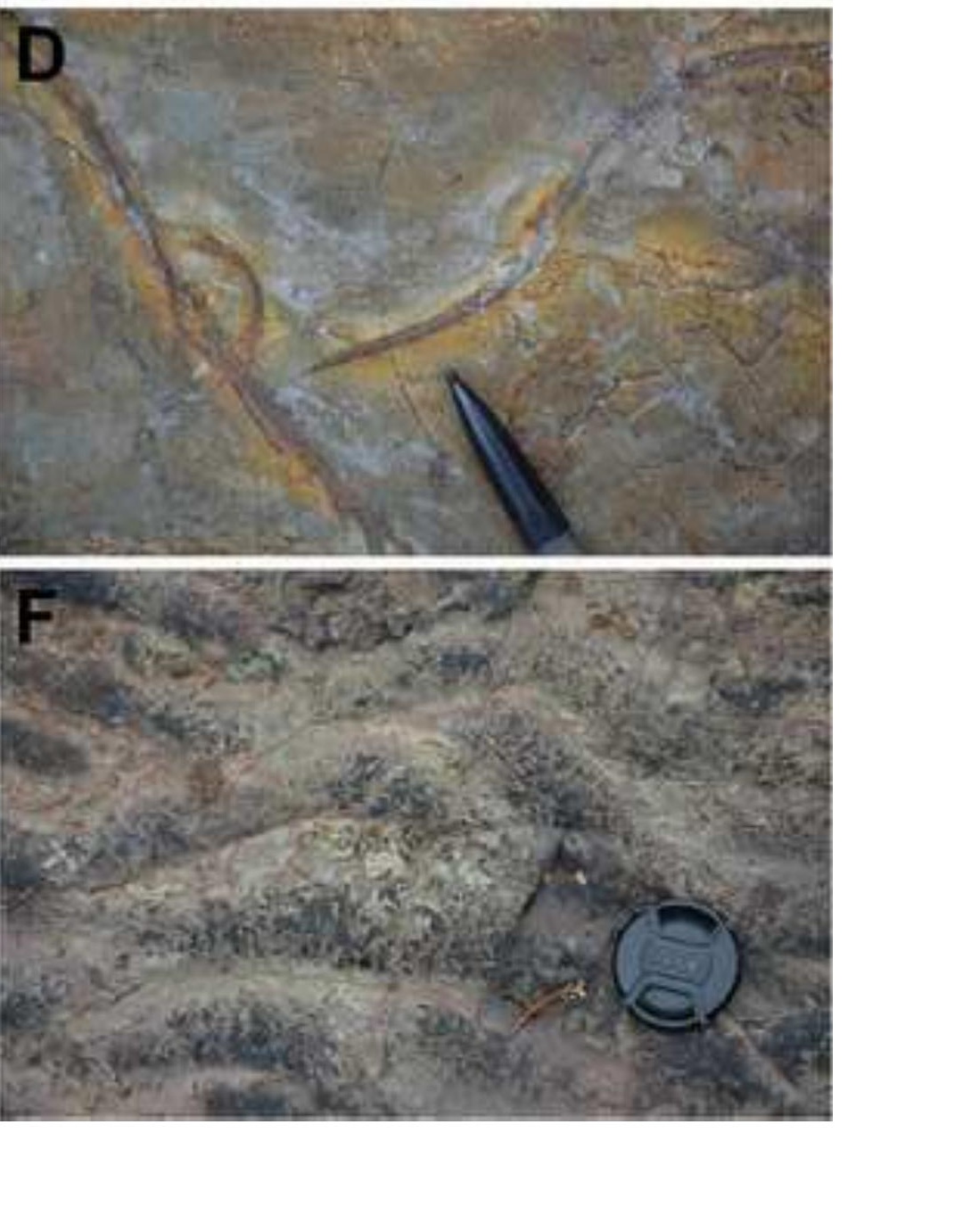


Click here to download high resolution image
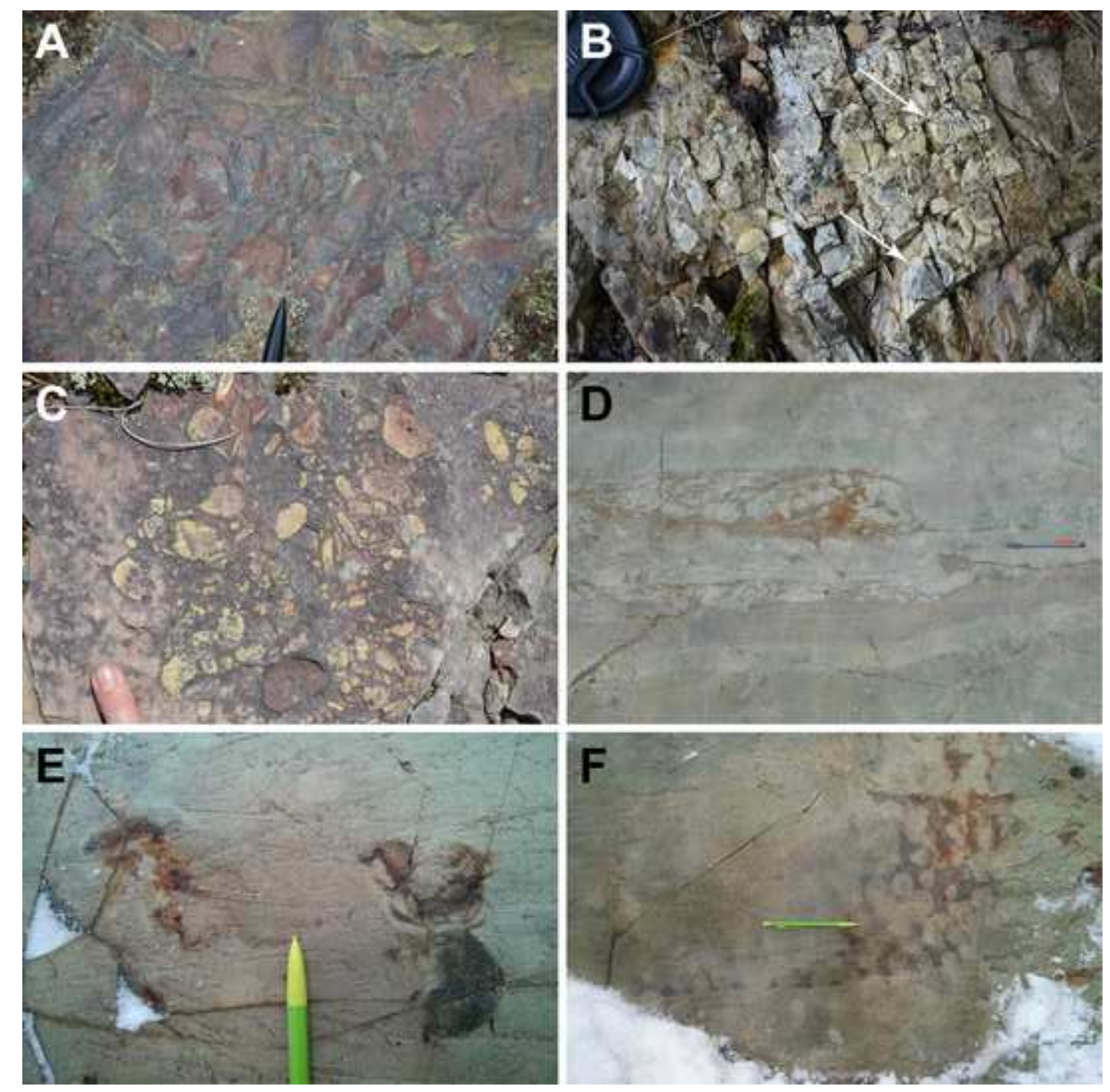

\section{.}

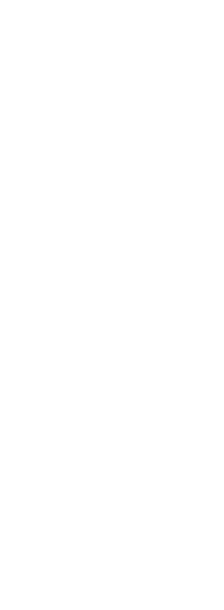


Click here to download high resolution image
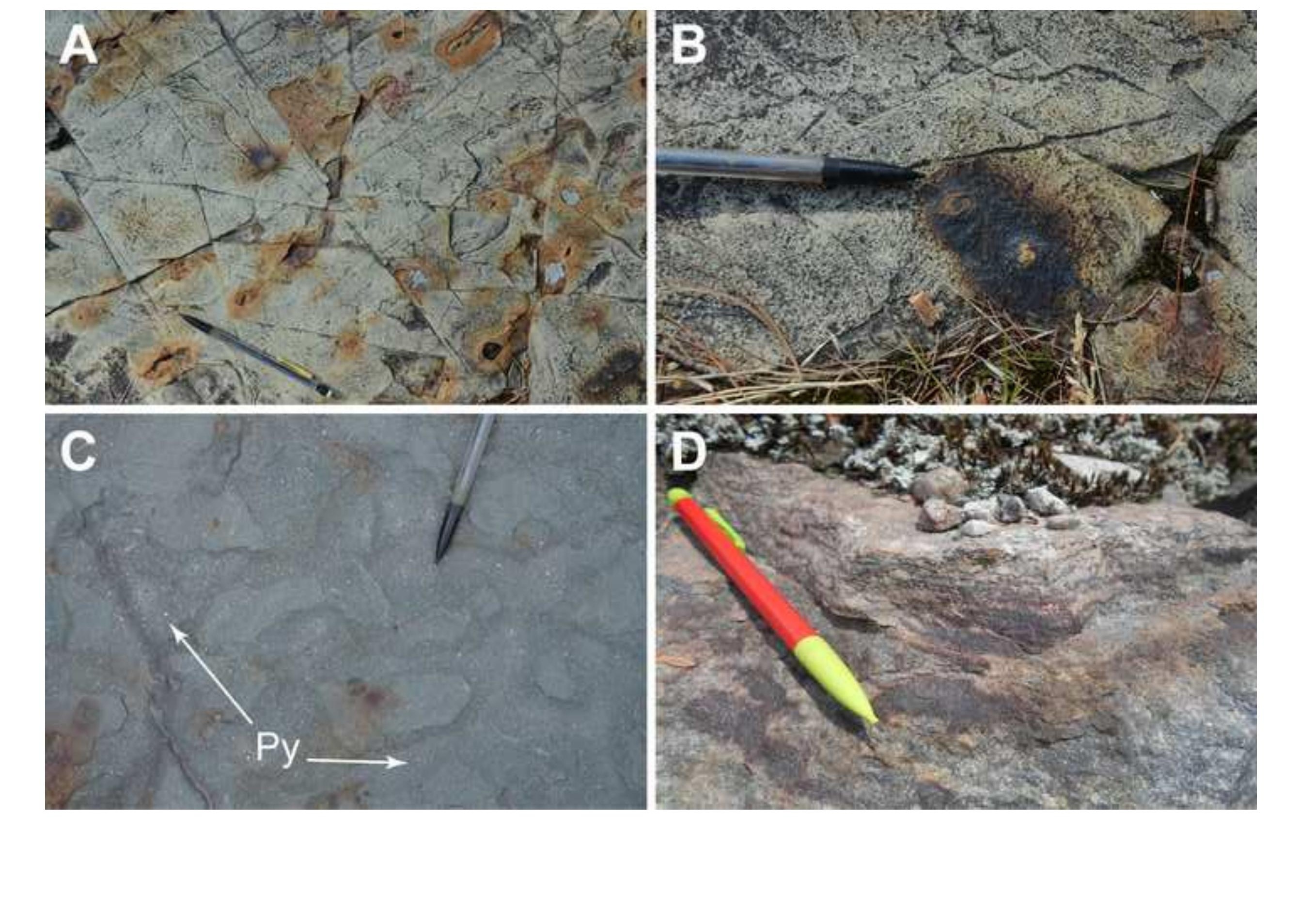

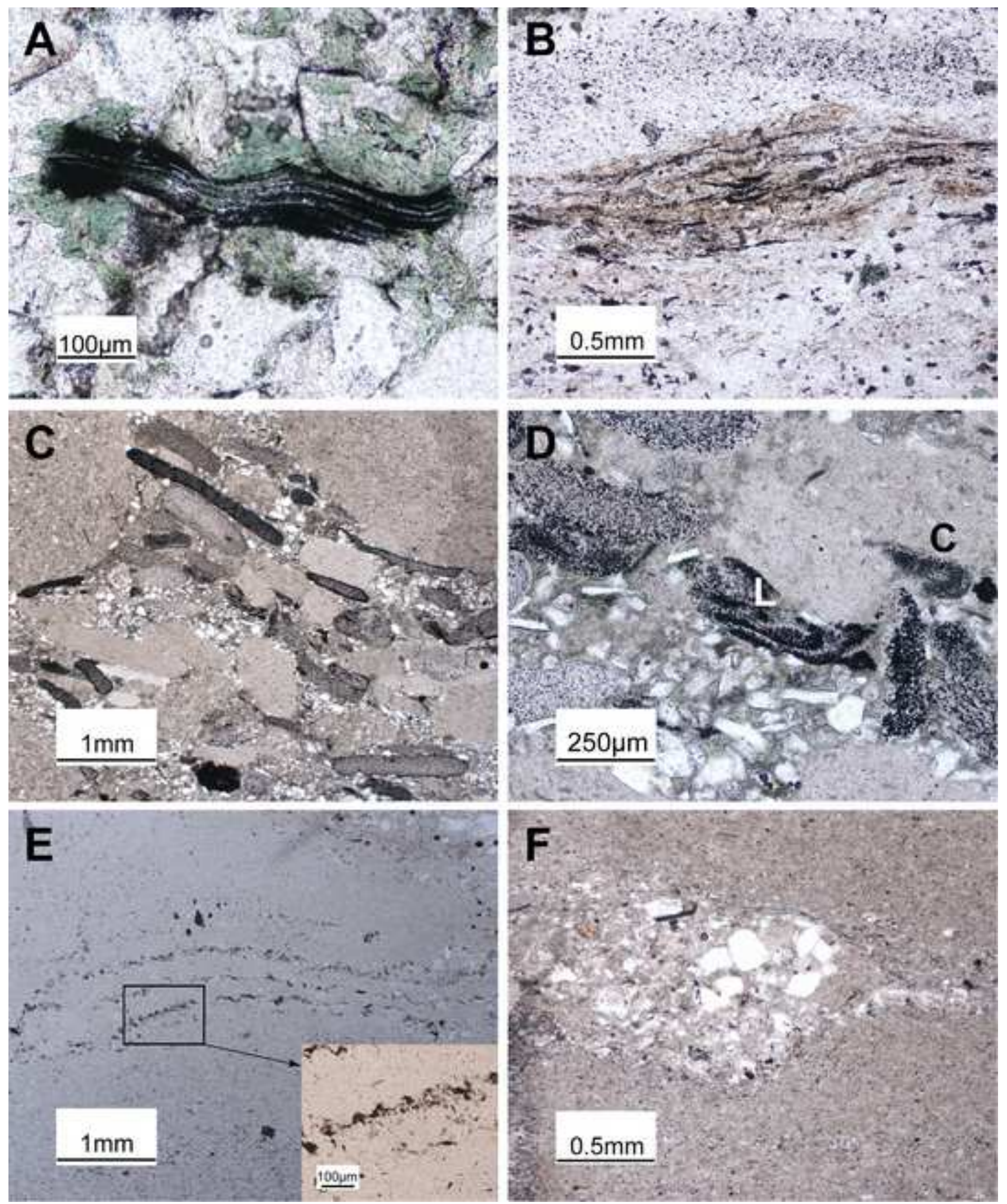


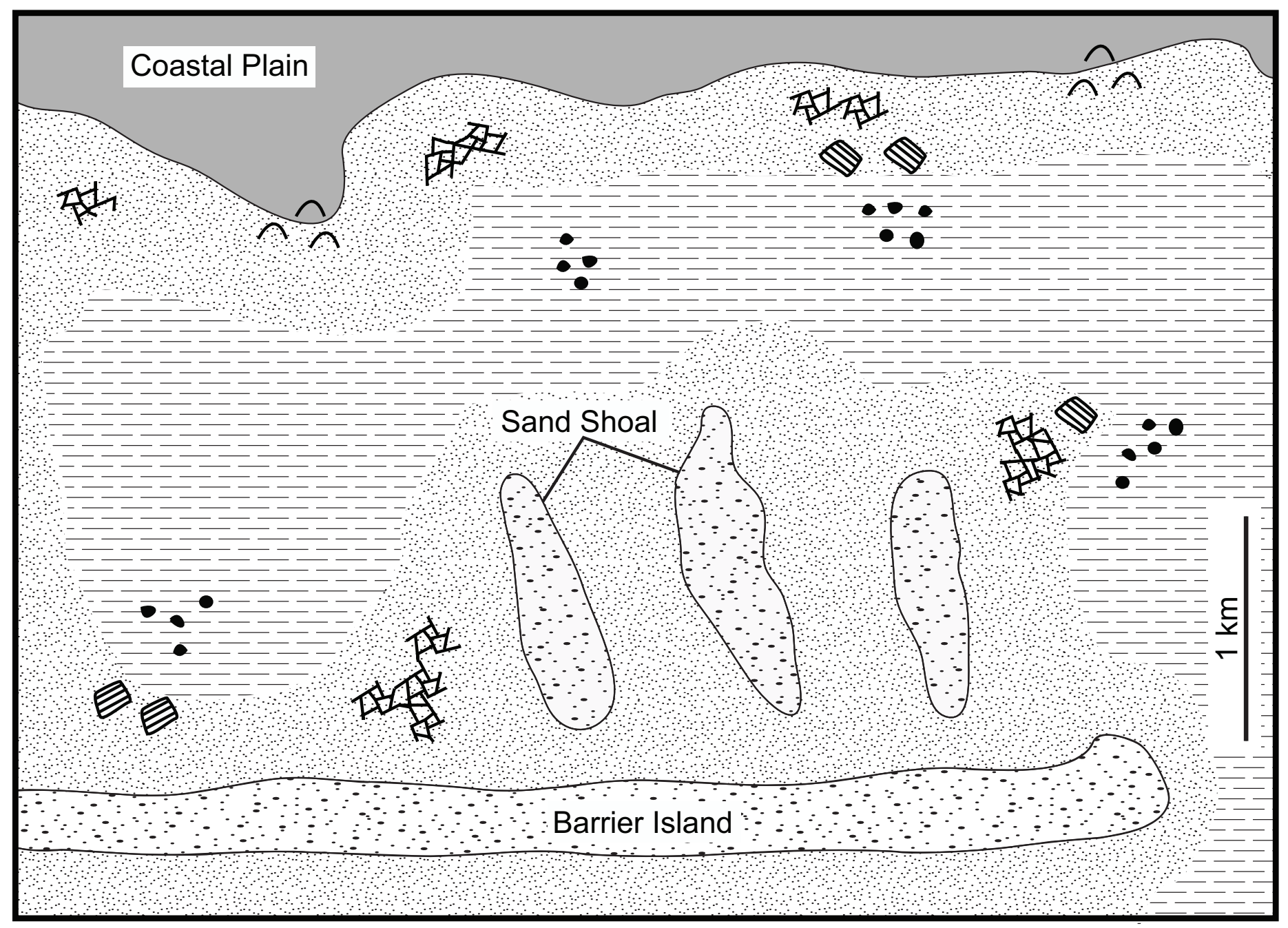

$\because$ Small mat chips

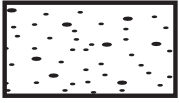

Coarse-grained sediments

$\checkmark$ Large mat chips

Medium-grained sediments

fy Sand cracks

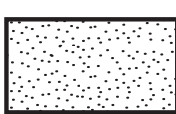

$\widehat{n}$ Gas domes 